\title{
Physiologically Based Pharmacokinetic Modeling of Metabolic Interactions between n-Hexane and Toluene in Humans
}

\author{
Xiaozhong Yu', Gunnar Johanson ${ }^{2}$, Gaku Ichihara', Eiji Shibata ${ }^{3}$, \\ Michihiro KamiJima ${ }^{1}$, Yuichiro $\mathrm{ONO}^{4}$ and Yasuhiro TaKeUCHI ${ }^{!}$ \\ 'Department of Occupational and Environmental Health, Nagoya University Graduate School of Medicine, \\ ${ }^{2}$ Department of Occupational Medicine-Toxicology, National Institute for Working Life, S-171 84 Solna, Sweden, \\ ${ }^{3}$ Department of Medical Technology, Nagoya University School of Medical Sciences and \\ ${ }^{4}$ Department of Public Health, Fijita Health University School of Medicine
}

\begin{abstract}
Physiologically based Pharmacokinetic Modeling of Metabolic Interactions Between nHexane and Toluene in Humans: Xiaozhong $\mathrm{Yu}$, et al. Department of Occupational and Environmental Health, Nagoya University Graduate School of Medicine-Some animal experiments have shown that mutual metabolic inhibition takes place between $n$ hexane and toluene, but we have found only one report dealing with their metabolic interaction at occupationally relevant exposure levels (Bælum et al. 1998). In order to evaluate the effect of dose-dependent metabolic interaction between toluene and $n$-hexane, especially in occupationally relevant exposure conditions such as relevant exposure levels, physical activities and exposure patterns, a physiologically based pharmacokinetic (PBPK) model for co-exposure to $n$ hexane and toluene was developed. The PBPK model for the binary co-exposure was established by initially validating or refining the existing PBPK models for $n$ hexane and toluene and then linking the individual solvent models via the hepatic metabolism terms. In reporting previous findings, noncompetitive inhibition was assumed and the inhibition constant of toluene on $n$-hexane biotransformation and that of n-hexane on toluene biotransformation used in simulation were 7.5, $30 \mu \mathrm{m}$, respectively, in previous data. According to the model, $8 \mathrm{~h}$ of constant exposure to $50 \mathrm{ppm} \mathrm{n-}$ hexane and 25,50,100 and $500 \mathrm{ppm}$ toluene will cause about $7 \%, 18 \%, 62 \%$ and $96 \%$ decreases in the urinary excretion of 2,5-hexanedione (2,5-HD) and $4 \%, 10 \%$, $25 \%$ and $30 \%$ increases in the n-hexane concentration in blood at the end of the fifth day of exposure simulated in a standard man at a $25 \mathrm{~W}$ work load. Simulations of co-exposure to $50 \mathrm{ppm} n$-hexane and $50 \mathrm{ppm}$ toluene
\end{abstract}

Received June 26, 1998; Accepted Aug 30, 1998

Correspondence to: $X$. $Y u$, Department of Occupational and Environmental Health, Nagoya University Graduate School of Medicine, 65 Tsurumai-cho, Showa-ku, Nagoya 466-8550, Japan in a standard man who inhaled $50 \mathrm{ppm} n$-hexane with 0 or $50 \mathrm{ppm}$ toluene for $8 \mathrm{~h}$ at different work loads suggest that toluene causes a slight decrease in urinary $2,5-\mathrm{HD}$ in the resting condition, a $17 \%$ decrease at 25 $\mathrm{W}$, and a $41 \%$ decrease at $50 \mathrm{~W}$ work load. The simulations of co-exposure in different exposure patterns with the same time-weighted concentration (TWA) of $50 \mathrm{ppm}$, i.e. $50 \mathrm{ppm}$ for $8 \mathrm{~h}, 100 \mathrm{ppm}$ of 4 times for $1 \mathrm{~h}$ and $200 \mathrm{ppm}$ of twice for $1 \mathrm{~h}$, showed reductions in urinary $2,5-\mathrm{HD}$ of $17 \%, 40 \%$ and $67 \%$, respectively. These simulations suggest that coexposure to $n$-hexane and toluene around $50 \mathrm{ppm}$ (TWA) could affect urinary $n$-hexane metabolites to various degrees depending on the fluctuations in exposure concentrations and variety of work activities in the workplace.

(J Occup Health 1998; 40: 293-301)

Key words: n-Hexane, Toluene, Co-exposure, Metabolic interaction, PBPK model

Multiple exposure to solvents is often observed in workplaces ${ }^{1,2)}$. Toxicokinetic interactions following multiple exposure to solvents have been studied in animals as well as in humans, volunteers and occupationally exposed subjects ${ }^{36)}$. Due to toxicokinetic interactions, the behaviour of the biological exposure indicators used to assess the degrees of exposure may vary significantly in relation to working conditions $s^{78}$. n-Hexane and toluene are common solvents in workplaces. ${ }^{90}$. Both are metabolized by the cytochrome P450 system, mainly in the liver ${ }^{11-13)}$. In animal experiments, Iwata et al $^{3,4}$ showed that simultaneous inhalation of $500 \mathrm{ppm} n$-hexane and $500 \mathrm{ppm}$ toluene decreased the urinary excretion of $n$-hexane metabolites. The exposure levels play a major role in influencing the magnitude of the metabolic interference. In a study on 
the interactions between toluene and benzene in which a multi-compartmental toxicokinetic simulation model was applied to a "standard male worker", Sato ${ }^{143}$ concluded that at low exposure concentrations of benzene and toluene each solvent slightly inhibits the metabolism of the other. It is frequently argued that whenever multiple exposure in the workplace is within the occupational exposure limit values, interactions rarely occur, and that in these situations the levels of the biological indicators therefore do not undergo any particular changes compared to exposure to single substances, but several reports are in conflict with these arguments ${ }^{15-17}$. Little is known with respect to the degree to which mutual interaction affects the toxicokinetic behavior of the $n$-hexane and toluene, especially in occupationally relevant exposure conditions.

Physiologically based pharmacokinetic (PBPK) modeling has been used to study the extrapolation of biological data from animals to humans, variability of biological exposure indicators as well as the metabolic interactions between ethanol and trichloroethylene ${ }^{18}$, toluene and $\mathrm{m}$ xylene $^{19)}, 1,3$-butadiene and styrene ${ }^{20)}$, and ethanol and 2-butoxyethanol ${ }^{21)}$. As an effort to evaluate the effect of dosedependent metabolic interaction between toluene and $n$-hexane, especially in occupationally relevant exposure conditions such as relevant exposure levels, and physical activities and exposure patterns, a physiologically based pharmacokinetic (PBPK) model for the co-exposure to $n$-hexane and toluene was developed.

\section{Methods}

\section{Simulation Model}

The pharmacokinetic simulation models for $n$-hexane and toluene were modified from Perbellini et al. ${ }^{22.23\}}$, and Ramsey and Anderson ${ }^{24}$. Each model is composed of five physiological compartments, as depicted in Fig. 1, including a lung compartment (LC), a vessel rich compartment (VRC), a vessel poor compartment (VPC), a fat tissue compartment (FC), and a liver tissue compartment (Liver). According to the studies on the metabolism of $n$ hexane ${ }^{11,13)}$, the metabolic pathway of $\mathrm{n}$-hexane can be expressed briefly in two steps (Fig. 1). The first step is the hydroxylation of $n$-hexane to hexanols, whereas the second step is assigned to the further metabolism of hexanols to 2,5-hexanedione (2,5-HD) and other metabolites. All metabolism and metabolic interactions were assumed to take place exclusively in the liver. The metabolisms of n-hexane to hexanols and of toluene to various metabolites were described by Michaelis-Menten kinetics. Mass balance was performed on each compartment, and the transfer of solvent throughout the system was expressed in the form of the simultaneous differential equations given in Table 1. This model is based on the assumptions that the solvent immediately
n-Hexane

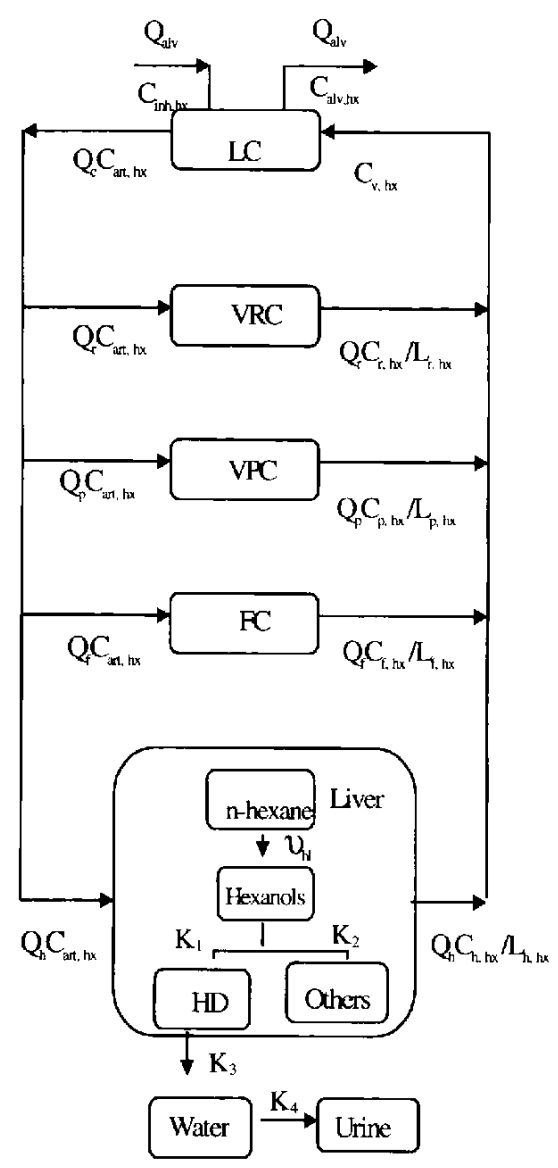

Toluene

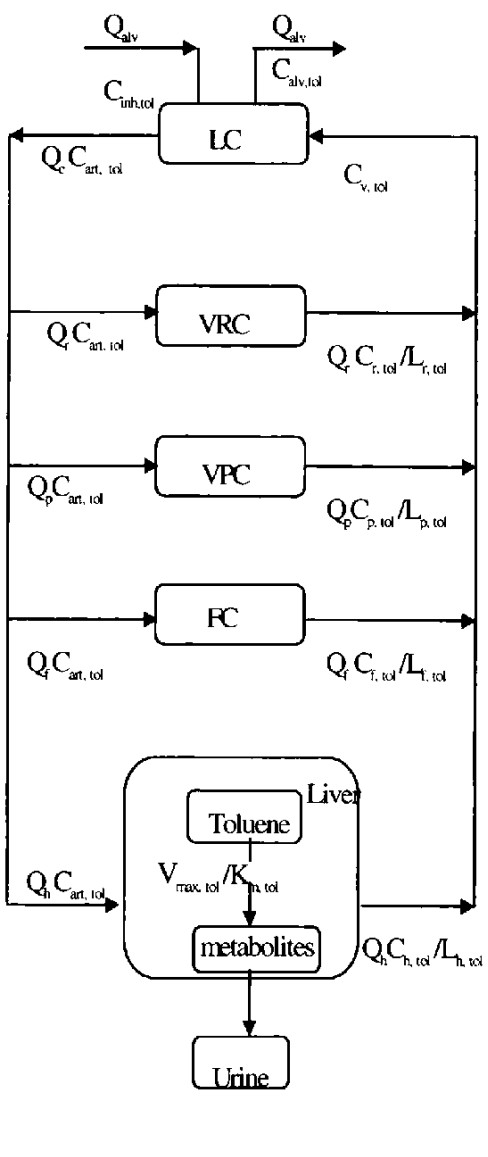

Fig. 1. Structure of PBPK model for combined inhalation exposure to $n$-hexane and toluene. LC: the lung compartment; VRC: the vessel-rich tissue compartment; VPC: the vessel-poor tissue compartment; FC: the fat compartment; Liver: the liver compartment; C: concentration in $\mathrm{mg} / \mathrm{l}$; L: Tissue/blood partition coefficient; Q: blood flow rate in L/min; subscripts alv and inh stand for alveolar air and inhaled air, respectively; $\mathrm{c}$ for cardiac output, l for lung, $r$ for VRC, $p$ for VPC, $f$ for $F C$, $h$ for liver, $v$ for venous, art for arterial, $h x$ for $n$-hexane, tol for toluene and 2,5-HD for 2,5-hexanedione. $v_{\mathrm{hl}}$ is the conversion rate of $n$-hexane to hexanols. $K_{1}$ and $\mathrm{K}_{2}$ represent the conversion of hexanols to 2,5-HD and other metabolites, respectively. $\mathrm{K}_{3}$ describes the transfer of 2,5-HD to the water compartment and $\mathrm{K}_{4}$ is the urinary excretion constant. 
Table 1. Mass balance differential equations for $n$-hexane in the PBPK model. Corresponding equations for toluene can be obtained from equations $1-5$.

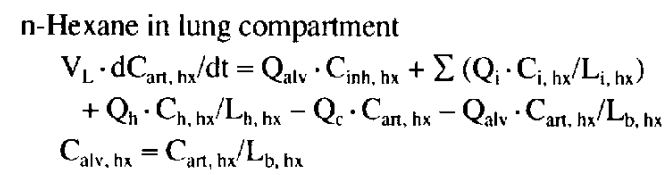

$\mathrm{n}$-Hexane in storage compartments

$$
\begin{aligned}
& V_{i} \cdot d C_{i, h x} / d t=Q_{i} \cdot\left(C_{a r t, h x}-C_{i, h x} / L_{i, h x}\right) \\
& V_{h} \cdot d C_{h, h x} / d t=Q_{h} \cdot\left(C_{a n t h x}-C_{h, h x} / L_{h, h x}\right)-v_{h, h x}
\end{aligned}
$$

Conversion of $\mathrm{n}$-hexane to hexanols in liver compartment

$$
v_{\mathrm{h}, h x}=\mathrm{V}_{\mathrm{max}, \mathrm{hx}} \cdot \mathrm{C}_{\mathrm{h}, \mathrm{hx}} /\left(\left(\mathrm{K}_{\mathrm{m}, \mathrm{hx}}+\mathrm{C}_{\mathrm{h}, \mathrm{hx}}\right)\left(1+\mathrm{C}_{\mathrm{h}, \text { tol }} / \mathrm{K}_{\mathrm{i}, \text { tol }}\right)\right)
$$

2,5-Hexanedione in liver compartment

$$
\mathrm{dA}_{\mathrm{h}, \mathrm{hd}} / \mathrm{dt}=\mathrm{K}_{\mathrm{l}} /\left(\mathrm{K}_{\mathrm{l}}+\mathrm{K}_{2}\right) \cdot v_{\mathrm{h}, \mathrm{hx}}-\mathrm{K}_{3} \cdot \mathrm{A}_{\mathrm{h}, \mathrm{hd}}
$$

2,5-Hexanedione in water compartment

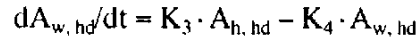

2,5-Hexanedione in urine

$$
\mathrm{dA}_{\mathrm{u}, \text { hd }} / \mathrm{dt}=\mathrm{K}_{4} \cdot \mathrm{A}_{\mathrm{w}, \text { hd }}
$$

Variables A: amount; V: volume of compartment in $\ell$. Subscripts b: blood/air; i; compartments $\mathrm{r}$, f and p; u: urine; $w$ : water compartment, Other symbols are explained in Fig. 1. reaches a balance between alveolar air and arterial blood, and that the solvent in venous blood is in dynamic equilibrium with the corresponding tissue.

\section{Model Parameters}

Model parameters are listed in Table 2. Values for the volume and blood flow in individual compartments were assigned according to literature data ${ }^{21,25)}$. The blood: air and tissue: blood coefficients of $\mathbf{n}$-hexane were taken from Perbellini et al. ${ }^{26)}$, and the blood: air coefficient of toluene for humans was from Fiserova-Bergerova ${ }^{27)}$. The human tissue: blood coefficients were assumed to be the same as those of rats and shown by Gargas et al. ${ }^{28)}$ Values for maximum metabolic rate $\left(\mathrm{V}_{\max }\right)$ and Michaelis's constant $\left(\mathrm{K}_{\mathrm{m}}\right)$ for $\mathrm{n}$-hexane were taken from Perbellini et al. ${ }^{23)}$ The $\mathrm{V}_{\max }$ value for toluene was scaled from animal experiments according to the formula $4.8 \cdot$ (weight $^{0.75}$ for humans, whereas $K_{m}$ was assumed to be the same across species ${ }^{(9)}$. The conversion of hexanols to 2,5-HD and to other metabolites is defined by the rate constants

\begin{tabular}{|c|c|c|c|c|c|c|}
\hline \multirow[t]{2}{*}{ Compartment } & \multirow[t]{2}{*}{$\begin{array}{c}\text { Tissue Volume }{ }^{\mathrm{a}} \\
(l)\end{array}$} & \multicolumn{3}{|c|}{$\begin{array}{l}\text { Blood Flowc } \\
\text { (l/min) }\end{array}$} & \multicolumn{2}{|c|}{$\begin{array}{c}\text { Tissue/Blood Partition } \\
\text { Coefficient }\end{array}$} \\
\hline & & Rest & $25 W$ & 50 & n-Hexane & Toluene \\
\hline Lung (L) & $\mathrm{V}_{\mathrm{L}}^{\mathrm{b}}$ & $\mathrm{Q}_{\mathrm{c}}$ & $Q_{c}$ & $Q_{c}$ & & \\
\hline VRC & $0.0371 \mathrm{Wt}$ & $0.51 \mathrm{Q}_{\mathrm{c}}$ & $0.32 Q_{c}$ & $0.27 \mathrm{Q}_{\mathrm{c}}$ & $5^{d}$ & $4.64 \mathrm{~g}$ \\
\hline VPC & $0.6100 \mathrm{Wt}$ & $0.19 Q_{\mathrm{c}}$ & $0.41 Q_{c}$ & $0.51 \mathrm{Q}_{\mathrm{c}}$ & $6.2^{\mathrm{d}}$ & $1.54 \mathrm{~g}$ \\
\hline FC & $0.2310 \mathrm{Wt}$ & $0.05 \mathrm{Q}_{\mathrm{c}}$ & $0.06 \mathrm{Q}_{\mathrm{r}}$ & $0.06 \mathrm{Q}_{\mathrm{c}}$ & $130^{\mathrm{d}}$ & $56.7 \mathrm{~g}$ \\
\hline LIVER & $0.0314 \mathrm{Wt}$ & $0.25 \mathrm{Q}_{\mathrm{c}}$ & $0.21 \mathrm{Q}_{\mathrm{c}}$ & $0.16 Q_{c}$ & $6.5^{\mathrm{d}}$ & 4.649 \\
\hline \multicolumn{7}{|l|}{ Parameter } \\
\hline \multicolumn{2}{|c|}{ Cardiac output $\left(Q_{c}\right)(/ / \mathrm{min})$} & 5.8 & 7.55 & 10.05 & & \\
\hline \multicolumn{2}{|c|}{ Alveolar ventilation $(/ / \mathrm{min})$} & 5.8 & 9 & 18 & & \\
\hline \multicolumn{5}{|c|}{ Blood/air partition coefficient } & $0.80^{d}$ & $16.3^{\mathrm{h}}$ \\
\hline \multicolumn{5}{|c|}{$\operatorname{Vmax}(\mathrm{mg} / \mathrm{min})$} & $0.50^{\mathrm{e}}$ & 1.94 \\
\hline \multicolumn{5}{|c|}{$\mathrm{Km}(\mathbf{m g} / l)$} & $0.587^{\mathrm{e}}$ & $0.55^{\prime}$ \\
\hline \multicolumn{5}{|l|}{$\mathbf{K}_{1} /\left(K_{1}+K_{2}\right)$} & 0.055 & \\
\hline \multicolumn{5}{|l|}{$\mathbf{K}_{3}\left(\min ^{-1}\right)$} & $0.003^{e}$ & \\
\hline \multicolumn{5}{|c|}{$\mathrm{K}_{4}\left(\min ^{-1}\right)$} & $0.0009^{\mathrm{c}}$ & \\
\hline \multicolumn{5}{|c|}{ Inhibitory constant of toluene in relation to n-hexane $\left(\mathbf{K}_{\mathrm{i}, \text { tol }}\right)(\mu \mathrm{M})$} & $7.5^{f}$ & \\
\hline \multicolumn{5}{|c|}{ Inhibitory constant of $\mathbf{n}$-hexane in relation to toluene $\left(\mathbf{K}_{\mathrm{i}, \mathrm{hx}}\right)(\mu \mathrm{M})$} & & $30^{\mathrm{f}}$ \\
\hline \multicolumn{2}{|c|}{ Urine output $\left(\mathrm{Q}_{\mathrm{u}}\right)(\mathrm{l} / \mathrm{min})$} & \multicolumn{3}{|c|}{$3.08 \cdot 10^{-5} \cdot w^{0.82 j}$} & & \\
\hline \multicolumn{2}{|c|}{ Body weight $(\mathrm{Wt})$} & \multicolumn{3}{|c|}{$70 \mathrm{~kg}$} & & \\
\hline
\end{tabular}
$\mathrm{K}_{1}$ and $\mathrm{K}_{2}$, respectively. The rate constant $\mathrm{K}_{3}$ describes the transfer of $2,5-\mathrm{HD}$ to the water compartment and $\mathrm{K}_{4}$ is the urinary excretion rate constant. Urinary metabolites account for about $15 \%$ of the $n$-hexane absorbed via

Table 2. Parameters used in the PBPK model for $n$-hexane and toluene

${ }^{a}$ From Davis and Mapleson ${ }^{25)}$. ${ }^{b} V_{L}=$ Volume of lung $(0.6 l)+$ volume of arterial blood ( 1.4 l) + FRC (2.7 l)/blood: air partition coefficient ${ }^{22)}$. "From Johanson et al. ${ }^{21)}$ d, e, f From Perbellini et al ${ }^{6,23,26)}$ g From Gargas et al. ${ }^{28)}{ }^{h}$ From Fiserova-Bergerova ${ }^{27)}$. ' From Tardif $e t$ al. ${ }^{19)}$ j From Adolph ${ }^{38)}$. 


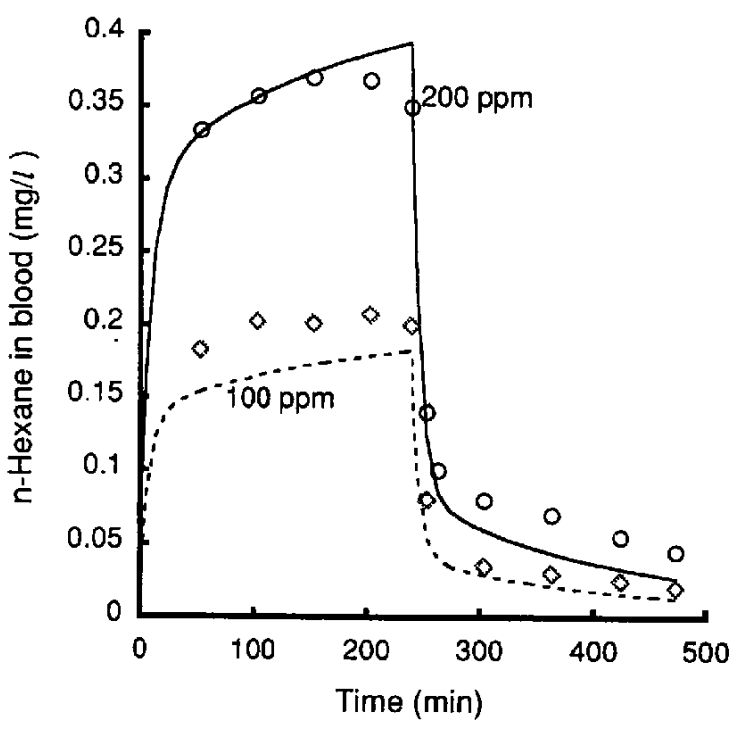

Fig. 2. Venous blood concentration of $n$-hexane during and after exposure to 100 or $200 \mathrm{ppm} n$-hexane for $4 \mathrm{~h}$ as suggested by the PBPK model. Spotted data are from Veulemans et al, ${ }^{33}$

inhalation ${ }^{29)}$. The average excretion of 2,5-HD in workers exposed to $100 \mathrm{ppm} n$-hexane for $8 \mathrm{~h}$ was found to be $2.8 \mathrm{mg}$ in $24 \mathrm{~h}^{30)}$. The estimated uptake of $\mathrm{n}$-hexane by the workers exposed to $100 \mathrm{ppm}$ for $8 \mathrm{~h}$ is about $338 \mathrm{mg}$, assuming an alveolar ventilation of $10 \mathrm{l} / \mathrm{min}$, and an alveolar retention of $20 \%{ }^{311}$, so that about $0.83 \%$ of absorbed $n$-hexane can be expected to be excreted as 2,5HD, corresponding to about $5.5 \%$ of urinary $n$-hexane metabolites. Therefore, the value for $\mathrm{K}_{1} /\left(\mathrm{K}_{1}+\mathrm{K}_{2}\right)$ was set at 0.055 .

\section{Modeling of metabolic interaction}

Noncompetitive metabolic interaction between $n$ hexane and toluene was assumed in view of the findings of Perbellini et al. ${ }^{6)}$ It was further assumed that n-hexane and toluene mutually interfered with each other in metabolism and that toluene affects the first step in $\mathbf{n}$ hexane metabolism. The above assumptions enabled us to express the rate of $n$-hexane metabolism under the influence of simultaneous exposure to toluene by means of the equation

$$
v_{h, h x}=\left(V_{\max } \cdot C_{h, h x}\right) /\left(\left(K_{m}+C_{h, h x}\right) \cdot\left(1+C_{h, \text { tol }} / K_{i, \text { tol }}\right)\right)
$$

where $\mathrm{V}_{\max }$ and $\mathrm{K}_{\mathrm{m}}$ stand for the metabolic constants of $\mathrm{n}$-hexane, $\mathrm{C}_{\mathrm{h}, \mathrm{hx}}, \mathrm{C}_{\mathrm{h}, \mathrm{tol}}$ the hepatic concentrations of $\mathrm{n}$ hexane and toluene, respectively, and $K_{i, \text { tol }}$ the $n$-hexane inhibitory constant of toluene. A similar equation may be used for the metabolism of toluene under the influence of $n$-hexane. The complete differential equations for the liver compartment are given in Table 1 . Solutions to the sets of simultaneous differential rate equations were

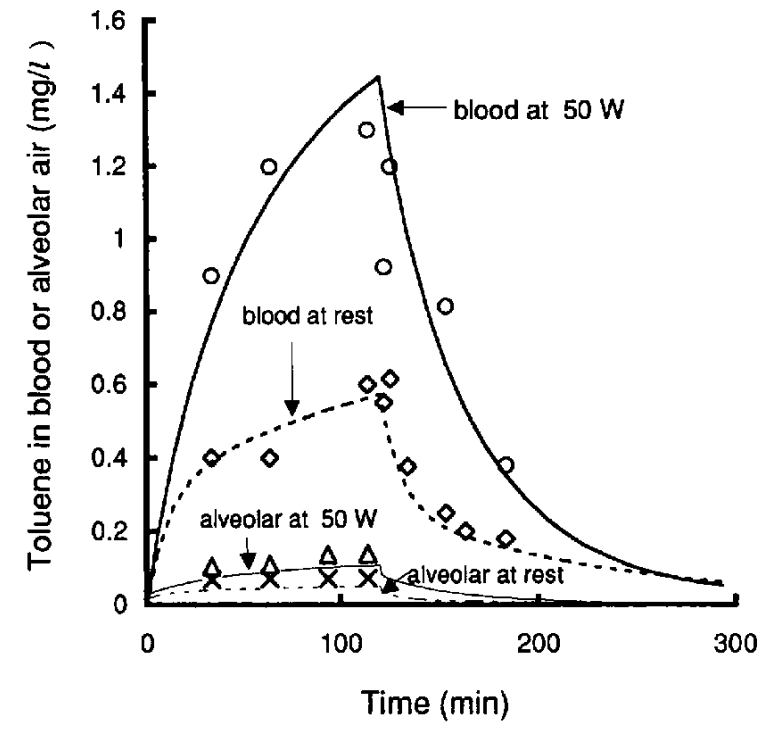

Fig. 3. Simulated pharmacokinetic behavior of toluene in blood and alveolar air during and after exposure to $300 \mathrm{mg} / \mathrm{m}^{3}(80 \mathrm{ppm})$ toluene for $120 \mathrm{~min}$ at rest or in $50 \mathrm{~W}$ work load condition. Spotted data are from Carlsson's human volunteer studies ${ }^{34)}$.

obtained by numeral integration with a spread sheet macro written in Microsoft Excel (version 5.0) ${ }^{32)}$.

\section{Results}

\section{Validation of PBPK model}

The behavior of venous blood concentrations of $n$ hexane during and after human exposure to $100 \mathrm{ppm} \mathrm{(360}$ $\left.\mathrm{mg} / \mathrm{m}^{3}\right)$ or $200 \mathrm{ppm}\left(720 \mathrm{mg} / \mathrm{m}^{3}\right)$ for $4 \mathrm{~h}$ in the resting condition with average lung ventilation of $10.4 \mathrm{l} / \mathrm{min}$ reported by Veulemans et al. ${ }^{33)}$ were well simulated in our PBPK model for n-hexane (Fig. 2). Furthermore, the calculated venous blood concentration and alveolar air concentration of toluene during and after $120 \mathrm{~min}$ exposure to $300 \mathrm{mg} / \mathrm{m}^{3}$ ( $\cong 80 \mathrm{ppm}$ ) at rest or with a $50 \mathrm{~W}$ work load were in general agreement with the experimental data reported by Carlsson ${ }^{34)}$ (Fig. 3), so it appears that our model is suitable for simulating the behavior of $\mathrm{n}$-hexane and toluene in human single exposure.

\section{Influence of toluene on $n$-hexane toxicokinetics}

The effects of toluene $+n$-hexane co-exposure on $n$ hexane levels in venous blood were simulated in a standard man who inhaled either $50 \mathrm{ppm}$ (A) or $500 \mathrm{ppm}$ (B) n-hexane together with $0,25,50,100$, or $500 \mathrm{ppm}$ toluene during very light physical exercise $(25 \mathrm{~W})$ for 8 $\mathrm{h}$ a day. The results are shown in Fig. 4. At $50 \mathrm{ppm}$ nhexane alone, the concentration in blood reached nearly $0.09 \mathrm{mg} / \mathrm{l}$ at the end of the workshift without any notable changes during one week of exposure (Fig. 4A). Coexposure to $25 \mathrm{ppm}$ toluene gave only a $4 \%$ increase in 

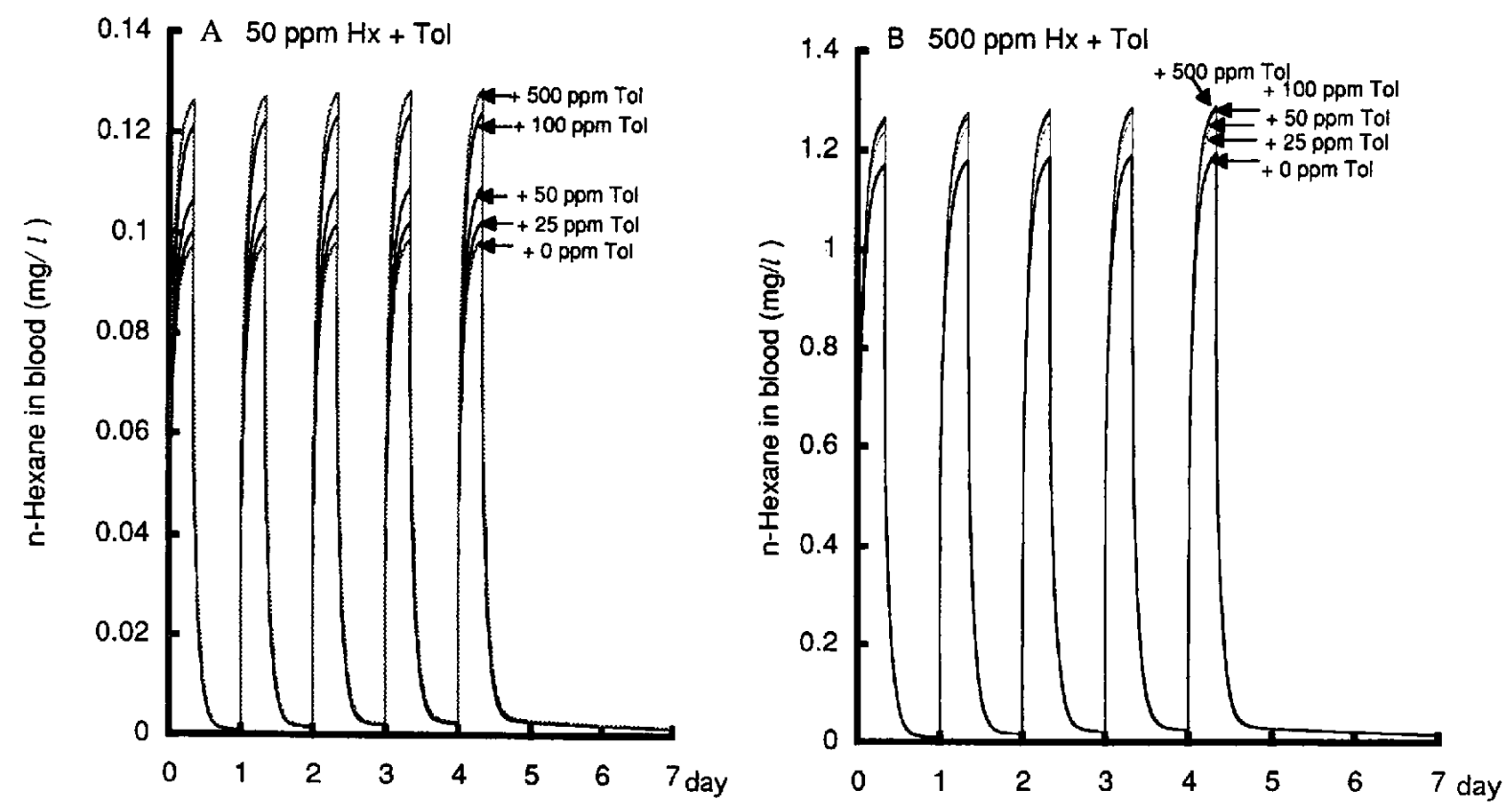

Fig. 4. PBPK predicted effect of co-exposure to $n$-hexane and toluene on the $n$-hexane concentration in venous blood. A standard man $(70 \mathrm{~kg}$ ) inhaled $50 \mathrm{ppm}(\mathrm{A})$ or $500 \mathrm{ppm}(\mathrm{B}) \mathrm{n}$-hexane with $25,50,100$ or $500 \mathrm{ppm}$ toluene for $8 \mathrm{~h}$ per day during light work $(25 \mathrm{~W})$.

blood $\mathrm{n}$-hexane levels, whereas 50,100 and $500 \mathrm{ppm}$ toluene caused marked increases in blood $\mathrm{n}$-hexane by $10 \%, 25 \%$ and $30 \%$, respectively. At the $500 \mathrm{ppm} \mathrm{n-}$ hexane level, co-exposure to $25,50,100$ and $500 \mathrm{ppm}$ toluene caused blood $\mathbf{n}$-hexane increases by $6 \%, 7 \%, 8 \%$ and $8 \%$, respectively, as compared with single exposure (Fig. 4B).

Simulated patterns of the urinary concentrations of 2,5HD are shown in Fig. 5. According to our model, urinary 2,5-HD reached a maximum of about $1.8 \mathrm{mg} / l$ after $8 \mathrm{~h}$ exposure on the first day. At repeated daily 8 -h exposure, 2,5-HD in urine increased gradually to a maximum of about $2.8 \mathrm{mg} / /$ on the fifth day. Upon co-exposure to 50 ppm n-hexane and $25 \mathrm{ppm}$ toluene, there was a $7 \%$ decrease in urinary $2,5-\mathrm{HD}$, but co-exposure to 50 or 100 ppm toluene reduced urinary $2,5-\mathrm{HD}$ by $18 \%$ and $62 \%$ and $500 \mathrm{ppm}$ toluene almost completely depressed it $(96 \%)$ (Fig. 5A). The corresponding reductions in urinary $2,5-\mathrm{HD}$ at $500 \mathrm{ppm} \mathrm{n}$-hexane were $18 \%, 37 \%, 70 \%$ and 95\% (Fig. 5B).

The simulated results of the effects of toluene on urinary 2,5-HD at different work loads are shown in Fig. 6. A standard man $(70 \mathrm{~kg})$ inhaled $50 \mathrm{ppm} \mathrm{n}$-hexane with 0 or $50 \mathrm{ppm}$ toluene for $8 \mathrm{~h}$ at 0,25 or $50 \mathrm{~W}$ work load. The percentages of reduction in urinary 2,5-HD were considerably different, so that there were $8 \%, 17 \%$ and $41 \%$ reductions under 0,25 and $50 \mathrm{~W}$ work load conditions, respectively, as compared with exposure to n-hexane only.
The effect of different patterns of co-exposure to toluene and n-hexane on $n$-hexane metabolites in the urine was studied by simulating a standard man $(70 \mathrm{~kg})$ inhaling $50 \mathrm{ppm} \mathrm{n}$-hexane together with 0 or $50 \mathrm{ppm}$ toluene, expressed as time-weighted averages for $8 \mathrm{~h}$ at a $25 \mathrm{~W}$ work load. The exposure patterns were: (A) continuous co-exposure to $50 \mathrm{ppm} \mathrm{n}$-hexane and $50 \mathrm{ppm}$ toluene for $8 \mathrm{~h}$, (B) four 1-h co-exposures to $100 \mathrm{ppm}$ n-hexane and $100 \mathrm{ppm}$ toluene during the day, and (C) two 1-h coexposures to $200 \mathrm{ppm} n$-hexane and $200 \mathrm{ppm}$ toluene. The results showed that urinary excretions of 2,5-HD were remarkably different for the different exposure patterns. There were $17 \%, 40 \%$ and $67 \%$ decreases in urinary 2,5-HD in patterns $\mathrm{A}, \mathrm{B}$ and $\mathrm{C}$ respectively, as compared to n-hexane alone (Fig. 7).

\section{Influence of $n$-hexane on toluene toxicokinetics}

Changes in the toluene concentration in mixed venous blood after co-exposure to toluene and $n$-hexane are shown in Fig. 8. Toluene in blood increased in a nonlinear fashion upon co-exposure to toluene and $\mathrm{n}$-hexane, so that $50 \mathrm{ppm}$ toluene plus 25 and $50 \mathrm{ppm} \mathrm{n}$-hexane caused $2 \%$ and $6 \%$ increases in blood toluene. Coexposure to 100 and $500 \mathrm{ppm} \mathrm{n}$-hexane, on the other hand, caused relative high increases in toluene in blood of $22 \%$ and $124 \%$, respectively (Fig. 8A). Co-exposure to 500 ppm toluene and $\mathrm{n}$-hexane $(25,50,100,500 \mathrm{ppm})$ induced less dramatic increases in toluene in blood $(2 \%, 4 \%, 6 \%$ and $11 \%$ ) (Fig. 8B). 

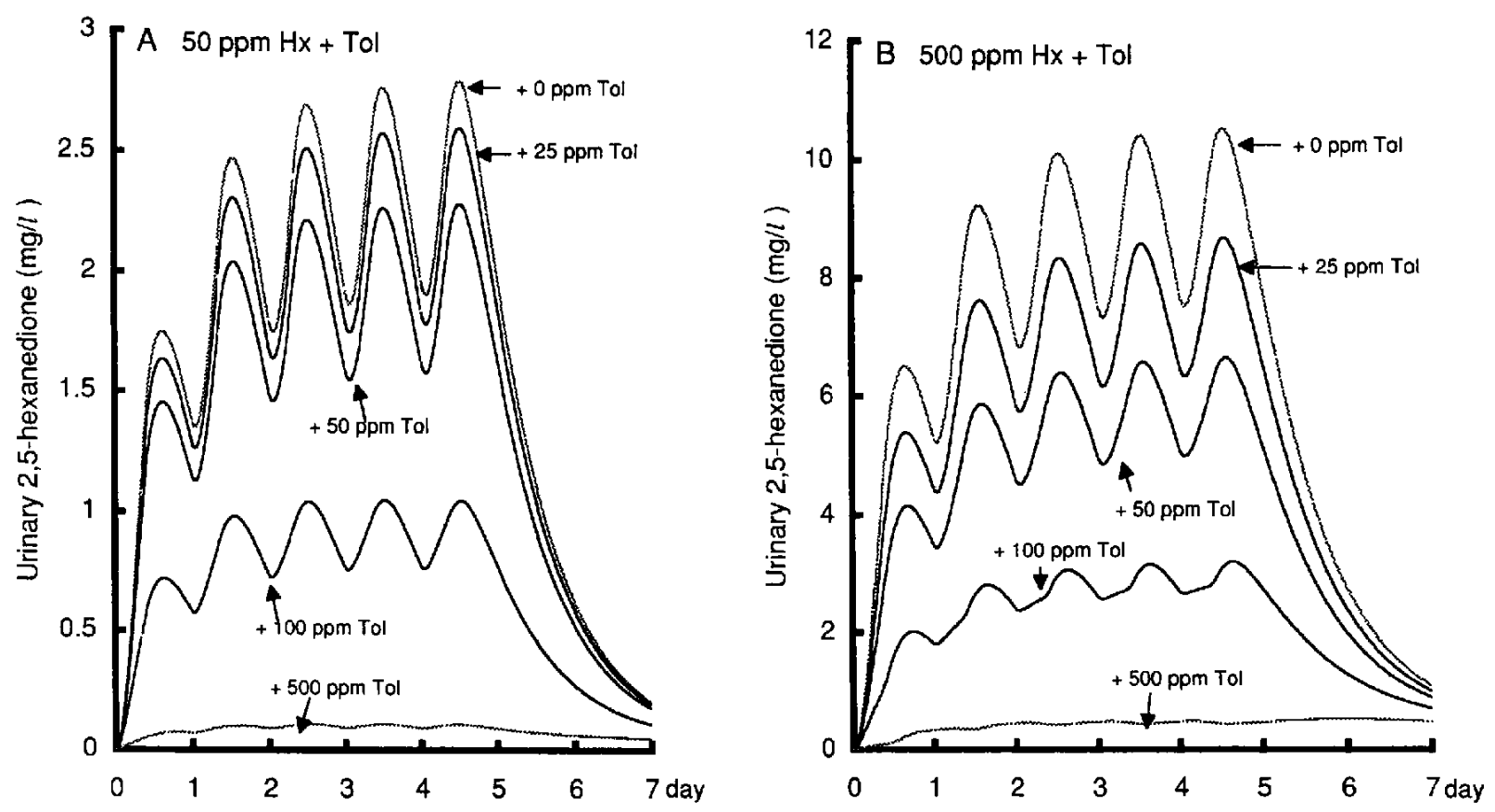

Fig. 5. PBPK predicted effect of co-exposure to $n$-hexane and toluene on urinary excretion of 2,5-hexanedione. A standard man (70 kg) inhaled $50 \mathrm{ppm}(\mathrm{A})$ or $500 \mathrm{ppm}$ (B) n-hexane with $25,50,100$ or $500 \mathrm{ppm}$ toluene for $8 \mathrm{~h}$ a day at $25 \mathrm{~W}$ work load.

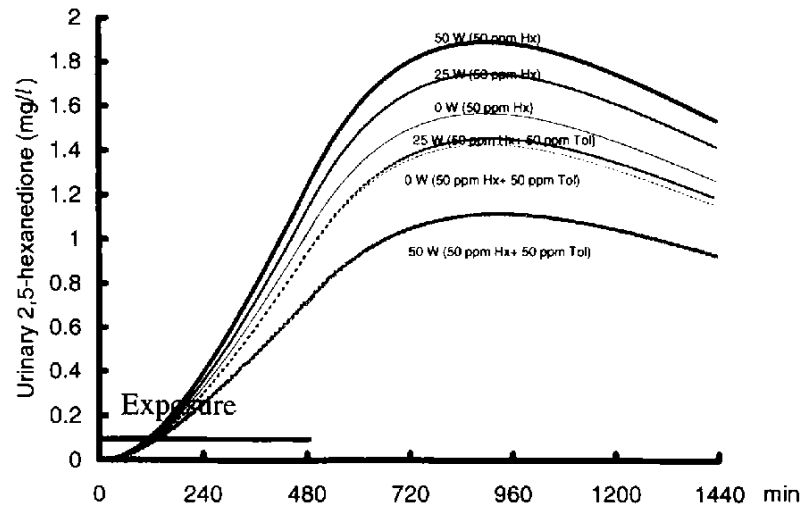

Fig. 6. Comparison of the effect of co-exposure to $n$-hexane and toluene on urinary excretion of 2,5-hexanedione in different physical activity as suggested by the PBPK model. A standard man $(70 \mathrm{~kg}$ ) inhaled $50 \mathrm{ppm} \mathrm{n-}$ hexane with 0 or $50 \mathrm{ppm}$ toluene for $8 \mathrm{~h}$ a day at 0,25 , or $50 \mathrm{~W}$ work load.

\section{Discussion}

The PBPK model for $n$-hexane was modified from the one presented by Perbellini ${ }^{22)}$, and the results for simulation of the kinetics of $\mathrm{n}$-hexane and 2,5-HD were similar to those already reported ${ }^{22,23)}$. In addition, the present model for toluene, which was scaled from a rat model, seems suitable to describe the toxicokinetics of

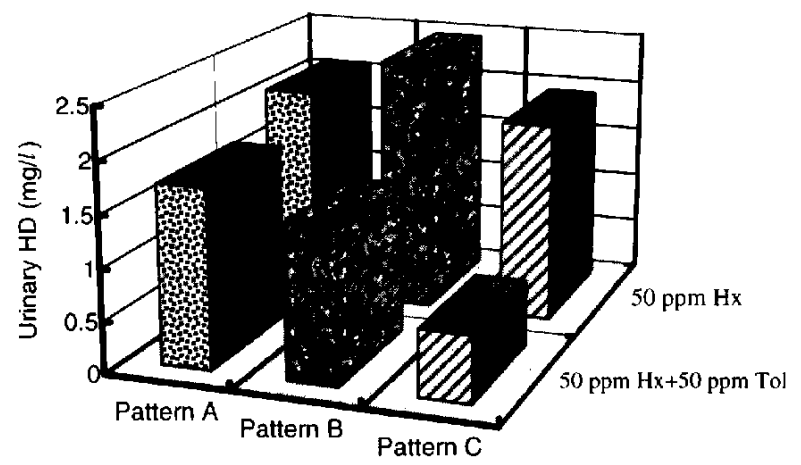

Fig. 7. Predicted effect of co-exposure to $n$-hexane and toluene on n-hexane metabolites in urine within different exposure scenarios, all with equal timeweighted averages of $50 \mathrm{ppm}$. All scenarios are 8 -h exposures of a standard man $(70 \mathrm{~kg}$ ) during light work $(25 \mathrm{~W})$. Scenarios: (A) Continuous exposure to 50 ppm n-hexane and 0 or $50 \mathrm{ppm}$ toluene. (B) Four $1-\mathrm{h}$ exposures to $100 \mathrm{ppm} n$-hexane and 0 or $100 \mathrm{ppm}$ toluene. (C) Two $\mathrm{l}$-h exposures to $200 \mathrm{ppm} n$-hexane and 0 or $200 \mathrm{ppm}$ toluene.

toluene, as suggested by comparing computer simulations with human volunteer experimental data ${ }^{34}$.

There are few experimental observations as to whether co-exposure to toluene and $n$-hexane has any significant effect on the n-hexane concentration in human blood or urinary 2,5-HD. A field survey by Saito and Shibata ${ }^{351}$ 

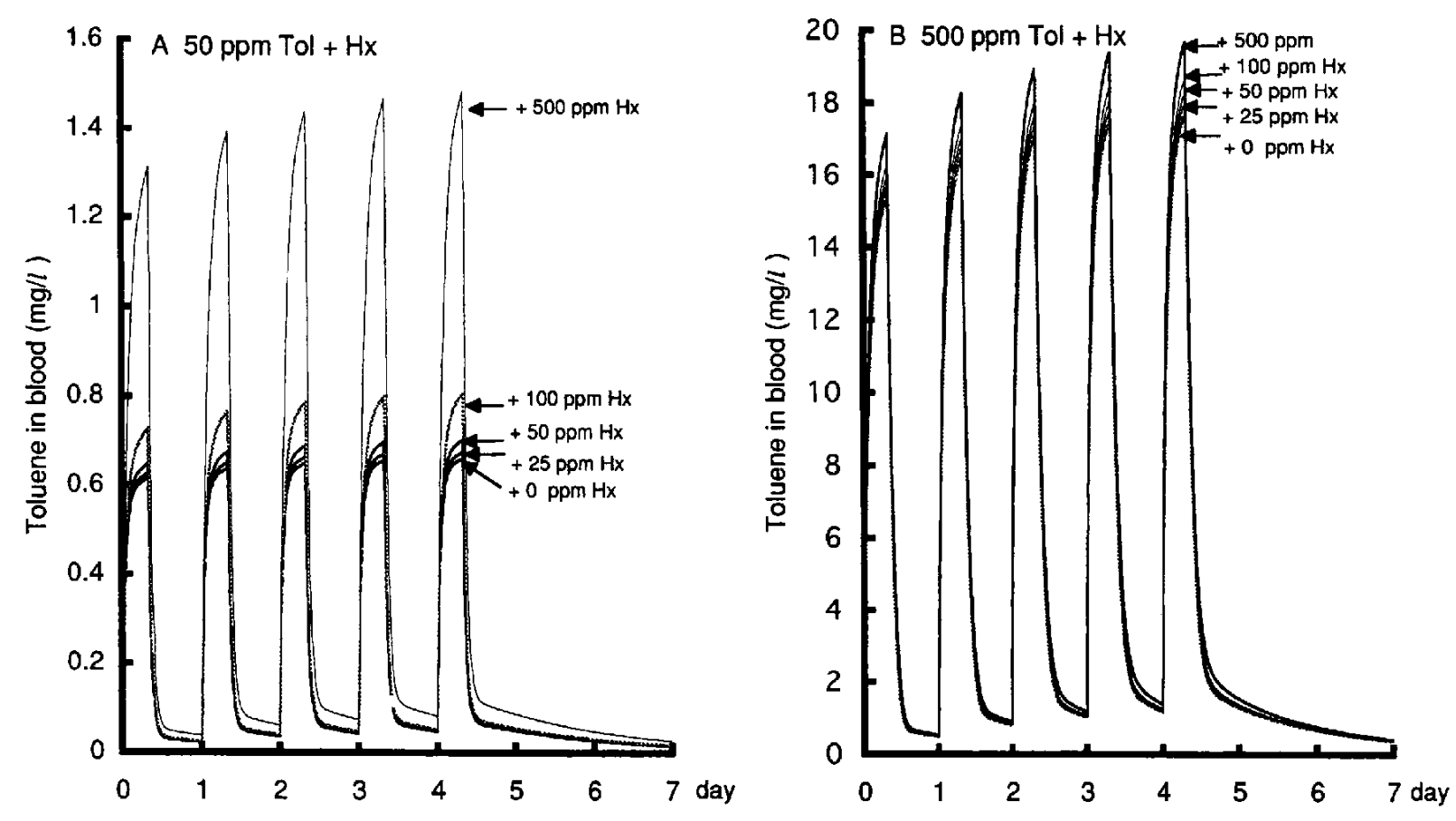

Fig. 8. PBPK predicted effect of co-exposure to $n$-hexane and toluene on toluene concentration in venous blood. A standard man $(70 \mathrm{~kg}$ ) inhaled $50 \mathrm{ppm}$ (A) or $500 \mathrm{ppm}$ (B) toluene with $25,50,100$ or $500 \mathrm{ppm}$ n-hexane for $8 \mathrm{~h}$ a day at $25 \mathrm{~W}$ work load.

indicated a slight decrease in urinary 2,5-HD in workers simultaneously exposed to $n$-hexane and toluene at levels as low as $10-40 \mathrm{ppm}$ (TWA). Cardona et al. also observed a tendency to a decrease in urinary $2,5-\mathrm{HD}$ in workplaces ${ }^{36)}$. Bxlum ${ }^{151}$ et al. reported their recent study on the mutual metabolic interaction between toluene, trichloroethylene and $n$-hexane. Eight health male volunteers were exposed to combinations of toluene ( 1.5 or $4 \mathrm{mg} / \mathrm{min}$ ), trichloroethylene ( 1.5 or $4 \mathrm{mg} / \mathrm{min}$ ) and $\mathrm{n}$ hexane $(0.3$ or $1.0 \mathrm{mg} / \mathrm{min})$ for $60 \mathrm{~min}$. The effects of the above dose rates to the liver are comparable with those obtained by inhalation of concentrations at the actual Danish occupational exposure limits $(50 \mathrm{ppm}$ for toluene, $30 \mathrm{ppm}$ for trichloroethylene and $50 \mathrm{ppm}$ for $\mathrm{n}$ hexane).There was no effect of either toluene or trichloroethylene co-exposure on the excretion of 2,5HD during a $240 \mathrm{~min}$ period after co-exposure, but coexposure to $n$-hexane and toluene at a high rate decreased the hippuric acid excretion by $18 \%$. The extent of hepatic metabolism of solvents in vivo during combined exposure is determined by the relation between the intrinsic metabolic clearances ( $\mathrm{CLi}$ ) (In the case of noncompetitive inhibition, $\mathrm{CLi}=\left(\mathrm{V}_{\max } /\left(\left(\mathrm{K}_{\mathrm{m}}+\mathrm{C}_{\mathrm{n}, \mathrm{a}}\right)\left(1+\mathrm{C}_{\mathrm{n}, \mathrm{b}} / \mathrm{k}_{\mathrm{i}}\right)\right)\right.$, where $\mathrm{C}_{\mathrm{h}, \mathrm{a}}$, and $\mathrm{C}_{\mathrm{h}, \mathrm{b}}$ are the hepatic concentrations of substances $\mathrm{A}$ and $\mathrm{B}$, respectively) and the hepatic blood flow ${ }^{37}$. When $\mathrm{CLi}$ is much larger than hepatic blood flow, the blood flow rate limits the metabolism. Conversely, when CLi is considerably smaller than hepatic blood flow, the enzyme capacity becomes the rate limiting factor. The liver has a high capacity for metabolism of many organic solvents. Thus, at low exposure levels, blood flow limits the metabolism and metabolic interactions will not modify the overall clearance, neither the toxicokinetics or biological exposure indicators, to any significant extent. At high exposure levels, on the other hand, where metabolism approaches saturation, enzyme capacity becomes rate limiting, and interactions will affect the overall clearance more clearly. This suggests that there is a "threshold" level below which metabolic interaction is negligible. Obviously, it is of importance to identify such "thresholds" in the interpretation of biological monitoring data. Thus, for example, in controlled laboratory studies in volunteers Tardif $e t a l^{8)}$ observed a slowdown in toluene metabolism manifested by an increased concentration of toluene in blood and reduced urinary excretion of hippuric acid during $4 \mathrm{~h}$ co-exposure to $95 \mathrm{ppm}$ toluene and $80 \mathrm{ppm}$ xylene, but no changes in urinary metabolites were seen during $7 \mathrm{~h}$ exposure to 50 ppm toluene and $40 \mathrm{ppm}$ xylene.

The present PBPK simulations suggested that during combined exposure to $50 \mathrm{ppm} \mathrm{n}$-hexane and $25 \mathrm{ppm}$ toluene, the rate limiting step of metabolism is liver blood flow rather than intrinsic metabolic capacity. The effects of metabolic interactions on urinary 2,5-HD might be under the intra- or extra-individual variations, and therefore their interactions were hardly detected in 
experiments or field studies. Nevertheless, during coexposure to $50 \mathrm{ppm} \mathrm{n}$-hexane and $50 \mathrm{ppm}$ toluene the intrinsic metabolic capacity became critical, and the effects of metabolic interactions on urinary 2,5-HD could not be neglected, but there are still other factors affecting the degree of metabolic interaction during $n$-hexane and toluene co-exposure. Physical activity results in dramatic changes in alveolar ventilation, cardiac output and distribution of arterial blood, thus causing profound changes in the absorption and distribution of solvents. Our PBPK model therefore suggested that the metabolic interactions between $50 \mathrm{ppm} \mathrm{n}$-hexane and $50 \mathrm{ppm}$ toluene were not so dramatic in the resting condition, but became noticeable as work intensity increased. In addition, there are great fluctuations in exposure levels in workplaces. Our simulations with different exposure patterns suggest that the urinary excretion of 2,5-HD decreases noticeably by about $67 \%$ after two 1 -h coexposure to $200 \mathrm{ppm}$-hexane and $200 \mathrm{ppm}$ toluene but only marginally (17\%) at continuous $50 \mathrm{ppm}$ co-exposure for $8 \mathrm{~h}$. Considering great fluctuations in exposure concentrations and a variety of work activities in actual workplaces, co-exposure to $n$-hexane and toluene could reduce urinary 2,5-HD even at concentrations lower than occupational exposure limits. These factors should be considered when the binary metabolites are used for biological exposure indices for $n$-hexane and toluene under co-exposure conditions.

It should be mentioned that in our simulations inhibition constants $\left(\mathrm{K}_{\mathrm{i}}\right)$ were derived from rat experiments in vitro. Obviously, species differences between rats and man exist. In addition, several problems still remain when trying to extrapolate results for animals to man, short term in vivo and in vitro experiments to long term exposure conditions. The simulations presented here, however, suggest that dose-dependent interactions of $n$-hexane and toluene could occur in occupationally relevant exposure conditions. Such knowledge is valuable for biological monitoring as well as for risk assessment in combined exposure to $\mathrm{n}$-hexane and toluene.

Acknowledgment: This work was supported in part by a Grant-in-aid for Research (No. 08770269) from the Japanese Ministry of Education, Science, Sports and Culture and by a Grant from the Hori Information Promotion Foundation.

\section{References}

1) Ikeda M, Kasahara M. n-Hexane and benzene contents in gasoline for industrial purpose. Ind Health 1986; 24: 63-66.

2) Inoue $T$, Takeuchi $Y$, Hisanaga $N$, Ono $Y$, Iwata $M$, Ogata M, Saito K, Sakurai H, Hara I, Matsushita T and Ikeda $\mathrm{M}$. A nationwide survey on organic solvent components in various solvent products. Part 1 Homogeneous products such as thinners, degreasers and reagents. Ind Health 1983; 21: 175-183.
3) Iwata M, Takeuchi $Y$, Hisanaga N, Ono Y. Changes of $\mathrm{n}$-hexane neurotoxicity and its urinary metabolites by long term co-exposure with MEK or toluene. Int Arch Occup Environ Health 1984; 54: 273-281.

4) Iwata M, Takeuchi $Y$, Hisanaga N, Ono Y. Changes of $\mathrm{n}$-hexane metabolites in urine of rats exposed to various concentrations of $n$-hexane and to its mixture with toluene or MEK. Int Arch Occup Environ Health 1983; 53: $1-8$.

5) Tardif R, Goyal R, Brodeur J. Effect of simultaneous exposure to toluene and xylene on their respective biological exposure indices in human. Int Arch Occup Environ Health 1991; 63: 279-284.

6) Perbellini L, Leone R, Fracasso ME, Brugnone F, Venturini MS. Metabolic interaction between $n$-hexane and toluene in vivo and in vitro. Int Arch Occup Environ Health 1982; 50: 351-358.

7) Shibata E, Huang J, Ono $Y$, Hisanaga N, Iwata M, Saito $\mathrm{I}$, and Takeuchi $\mathrm{Y}$. Changes in urinary $\mathrm{n}$-hexane metabolites by co-exposure to various concentrations of methyl ethyl ketone and fixed $\mathrm{n}$-hexane levels. Arch Toxicol 1990; 64: 165-168.

8) Tardif R, Goyal R, and Brodeur J. Assessment of occupational health risk from multiple exposure: review of industrial solvent interaction and implication for biological monitoring of exposure. Toxicol Ind Health 1992; 8: 37-52.

9) Iwata $M$, Takeuchi $Y$, Hisanaga $N$, Ono $Y$. A study on biological monitoring of $\mathrm{n}$-hexane exposure. Int Arch Occup Environ Health 1983; 51: 253-260.

10) Kumai M, Koizumi A, Saito K, Sakurai H, Inoue T, Takeuchi Y, Ogata M, Matsushita T and Ikeda M. A nationwide survey on organic solvent components in various solvent products. Part 2 Heterogeneous products such as paints, inks and adhesives. Ind Health 1983; 21: 185-197.

11) Morohashi K, Sadano H, Okada Y, Omura T. Position specificity in $\mathrm{n}$-hexane hydroxylation by two forms of cytochrome $\mathbf{P} 450$ in rat liver microsomes. J Biochem Tokyo 1983; 93: 413-419.

12) Nakajima T, Wang RS. Induction of cytochrome $P 450$ by toluene. Int J Biochem 1994; 26: 1330-1340.

13) Toftgard R, Haaparanta T, Eng L, Halpert J. Rat lung and liver microsomal cytochrome $\mathbf{P} 450$ isozymes involved in the hydroxylation of $\mathbf{n}$-hexane. Biochem Pharmacol 1986; 35: 3733-3738.

14) Sato $A$. The effect of environmental factors on the pharmacokinetic behaviour of organic solvent vapours. Ann Occup Hyg 1991; 35: 525-541.

15) Bælum J, Mølhave L, Hansén SH, Væth M (1998)Metabolic interaction between toluene, trichloroethylene and n-hexane in humans. Scand J Work Environ Health 24: 30-37.

16) Wallen M, Holm S, Byfalt Nordqvist B. Coexposure to toluene and p-xylene in man: uptake and elimination. Brit J Ind Med 1985; 42: 111-116.

17) Jacubowski M, kostrezewski P. Excretion of Methylbenezoic acid in urine a result of single and combined exposure to m-xylene. Pol J Occup Med 1986; 2: 238-247. 
18) Sato A, Endoh K, Kaneko T, Johanson G. Effects of consumption of ethanol on the biological monitoring of exposure to organic solvent vapours: simulation study with trichloroethylene. Brit J Ind Med 1991; 48: $548-556$

19) Tardif R, Lapare S, Krishnan K, and Brodeur J. Physiologically based modelling of the toxicokinetic interaction between toluene and $\mathrm{m}-\mathrm{xylene}$ in the rat. Toxicol Appl Pharmacol 1993; 120: 266-273.

20) Filser JG, Johanson G, Kessler W, Kreuzer PE, Stei P, Baur C, Csanady GA. A pharmacokinetic model to describe toxicokinetic interactions between 1,3butadiene and styrene in rats: predictions for human exposure. IARC Sci Publ 1993; 127: 65-78.

21) Johanson G. Physiologically based pharmacokinetic modeling of inhaled 2-butoxyethanol in man. Toxicol Lett 1986; 34: 23-31.

22) Perbellini L, Mozzo P, Brugnone F, Zedde. Physiologicomathematical model for studying human exposure to organic solvents: kinetics of blood/tissue $\mathrm{n}$-hexane concentrations and of 2,5-hexanedione in urine. Brit J Ind Med 1986; 43: 760-768.

23) Perbellini L, Mozzo P, Olivato D, Brugnone F. "Dynamic" biological exposure indexes for $n$-hexane and 2,5-hexanedione, suggested by a physiologically based pharmacokinetic model. Am Ind Hyg Assoc J 1990; 51: 356-362.

24) Ramsey JC, Andersen ME. A physiologically based description of the inhalation pharmacokinetics of styrene in rats and humans. Toxicol Appl Pharmacol 1984; 73: 159-175.

25) Davis MR, Mapleson WW. Structure and quantification of physiological model of the distribution of injected agents and inhaled anaesthetics. Brit J Anaesth 1981; 53: 399-405.

26) Perbellini L, Brugnone F, Caretta D, Maranelli G Partition coefficient of some industrial aliphatic hydrocarbons (C5-C7) in blood and human tissues. Brit $\mathrm{J}$ Ind Med 1985; 42: 162-167.

27) Fiserova-Bergerova. Gases and their solubility: a review of fundamentals. In: Fiserova-Bergerova, eds. Modeling of inhalation exposure to vapor; uptake, distribution and elimination Vol I. Florida: CRC Press, Inc. Boca Raton. 1992: 3-28.

28) Gargas ML, Burgess RJ, Voisard DE, Cason GH, and
Andersen ME. Partition coefficients of low molecular weight volatile chemicals in various liquids and tissues. Toxicol Appl Pharmacol 1989; 98: 87-99.

29) Mutti A, Falzoi M, Lucertini S, Arfini G, Zignani M, Lombardi S, Francini I. n-Hexane metabolism in occupational exposure. Brit J Ind Med 1984; 41: 533 538.

30) Perbellini L, Bartolucci GB, Brugnone F, De Rosa E, Valentini F. 2,5-esandione nel contollo biologico dell' esposizone professionale a n-esano. Med Lav 1985; 76: $35-43$

31) Perbellini L, Brugnone F, Mozzo P, De Rosa $E$ Bartolucci GB, Facinni G. Toxicokinetic aspects of $n-$ hexane and 2,5-hexanedione in the biomonitoring of occupational exposure to $n$-hexane. Ann Am Conf Ind Hyg 1985; 12: 357-364.

32) Johanson G, Näslund PH. Spreadsheet programming: a new approach in physiologically based modelling of solvent toxicokinetics. Toxicol Lett 1988; 41: 115-127.

33) Veulemans $H$, Van Vlem E, Janssens $H$, Masschelein $R$, Leplat A. Experimental human exposure to $n$ hexane. Study of the respiratory uptake and elimination, and of n-hexane concentrations in peripheral venous blood. Int Arch Occup Environ Health 1982; 49: 251 263.

34) Carlsson A. Exposure to toluene, uptake, distribution and elimination in man. Scand J Work Environ Health 1982; 8: 43-55.

35) Saito I, Shibata E. Hisanaga N, Takeuchi Y, Huang J. Relationship between $n$-hexane and urinary 2,5 hexanedione of workers in shoe and bag factories. Jpn J Ind Health 1992; 34: 831 .

36) Cardona A, Marhuenda D, Marti J, Brugnone F, Roel J, Perbellini L. Biological monitoring of occupational exposure to $n$-hexane by measurement of urinary 2,5 hexanedione. Int Arch Occup Environ Health 1993; 65: 71-74.

37) Sato A, Johanson G. Physiological factors affecting the behaviour of organic solvent vapors in humans. In: Cheremisinoff PN, eds. Encyclopedia of environmental control technology. Vol 7. High hazard pollutants. Gulf Publishing Company, Houston, Texas, 1995: 53-80.

38) Adolph EF. Quantitative relations in the physiological constitutions of mammals. Sci 1949; 109: 579-585. 